\title{
Informatiegebruik in verant-
}

\section{woordingsgerichte en school-}

\section{ontwikkelingsgerichte onder-}

\section{wijssystemen: een Nederlands-}

Vlaams perspectief

Roos Van Gasse, Jan Vanhoof (Universiteit Antwerpen) en Willem de Vos (Hogeschool Rotterdam)

\section{URN:NBN:NL:UI:10-1-100769// PED201402}

\section{Samenvatting}

Wereldwijd wordt hoe langer hoe meer belang gehecht aan informatiegebruik in scholen. Hoewel verschillen in het informatiegebruik van scholen in onderzoek vaak gerelateerd worden aan een verantwoordingsgericht of schoolontwikkelingsgericht onderwijssysteem, is onderzoek dat informatiegebruik in verschillende onderwijssystemen diepgaand beschrijft en vergelijkt schaars. In deze studie onderzoeken we gelijkenissen en verschillen in het informatiegebruik van schoolleiders binnen een verantwoordingsgericht en een schoolontwikkelingsgericht onderwijssysteem, respectievelijk Nederland en Vlaanderen. De resultaten wijzen uit dat schoolleiders uit beide onderwijssystemen andere verwachtingen percipiëren inzake informatiegebruik, andere soorten informatie gebruiken en ook verschillen in de manieren waarop zij informatie gebruiken. Een opvallende vaststelling is dat sterkere verwachtingen naar verantwoording niet noodzakelijk in negatieve zin wegen op het schoolontwikkelingsgericht informatiegebruik van schoolleiders. 


\section{Inleiding}

Wereldwijd verwerft informatiegebruik binnen scholen een steeds prominentere plaats. Beleidsmakers lijken het er over eens te zijn dat informatiegebruik kan bijdragen tot betere beleids- en praktijkbeslissingen en verwachten daarom van scholen dat hun beleid gestoeld is op objectieve informatie eerder dan op intuïtie. De groeiende autonomie van scholen maakt dat beleidsmakers ten eerste verwachten dat scholen zelfstandig zijn in het bewaken en verbeteren van hun onderwijskwaliteit en dat informatie dus gebruikt wordt voor schoolontwikkeling. Daarnaast wordt van scholen echter ook verwacht dat ze op basis van objectieve parameters verantwoording afleggen over de eigen onderwijskwaliteit (Marsh, Pane, \& Hamilton, 2006; Schildkamp, Ehren, \& Lai, 2012). Voor scholen ontstaat er bijgevolg een tweespalt in de verwachtingen inzake informatiegebruik waarvan de balans, afhankelijk van het onderwijssysteem, meer kan overhellen naar schoolontwikkeling of naar verantwoording.

In schoolontwikkelingsgerichte onderwijssystemen ligt de focus van informatiegebruik op het ontwikkelen van kennis om tot beter lesgeven en leren te komen, wat een snelle opstap naar schoolontwikkeling kan teweegbrengen (O'Day, 2002), maar wat informatiegebruik ook sterk afhankelijk maakt van de competenties en motivatie van schoolleiders en leerkrachten, waardoor de gewenste resultaten niet altijd bereikt worden (O'Day, 2002; Sutherland, 2004). In verantwoordingsgerichte onderwijssystemen ligt de focus van informatiegebruik op (het verhogen van) leerlingenprestaties (O'Day, 2002), met een sterke doelgerichtheid, een systematische monitoring van leerlingenprestaties en betere resultaten tot gevolg (Wößmann, 2002). Een te sterke resultaatsgerichtheid van scholen kan er echter ook toe leiden dat schoolontwikkeling uit het oog verloren wordt (Schildkamp et al., 2012), met ongewenste strategieën om betere leerlingenprestaties te kunnen voorleggen (zoals 'teaching to the test' of het selecteren van leerlingen voor toetsen) tot gevolg (Ehren \& Swanborn, 2012; Van Petegem, Vanhoof, Daems, \& Mahieu, 2005).

Hoewel in de literatuur verschillen geponeerd worden met betrekking tot informatiegebruik in schoolontwikkelingsgerichte en verantwoordingsgerichte onderwijssystemen, is onderzoek dat informatiegebruik in verschillende onderwijssystemen diepgaand beschrijft en vergelijkt schaars. Daarom bestuderen we het informatiegebruik in twee zeer verschillende onderwijssystemen: Nederland en Vlaanderen. De aanwezigheid van centrale examens, de outputgerichte evaluatiemethode door de onderwijsinspectie en het bestaan van publieke databanken maken het Nederlandse onderwijssysteem sterker verantwoordingsgericht dan het Vlaamse, waarin geen cultuur is van centrale examens of publieke databanken en waar de onderwijsinspectie scholen eerder procesmatig evalueert (De Volder, 2012; OECD, 2013). De twee onderwijssystemen lenen zich dus tot een vergelijkende studie naar de impact van schoolontwikkelingsgerichte en verantwoordingsgerichte onderwijssystemen op het informatiegebruik van schoolleiders in basisscholen. Een eerste variabele die we in kaart 
brengen zijn de gepercipieerde verwachtingen inzake informatiegebruik. Uit de sterk outputgerichte evaluatiemethode van de Nederlandse onderwijsinspectie en de meer procesmatige aanpak van de Vlaamse onderwijsinspectie (De Volder, 2012; OECD, 2013) ontstaat de assumptie dat de verwachtingen inzake informatiegebruik volgens Nederlandse schoolleiders eerder vanuit een verantwoordingsperspectief en volgens Vlaamse schoolleiders eerder vanuit een schoolontwikkelingsperspectief zullen voortkomen. Vervolgens onderzoeken we de impact van deze verwachtingen op de doelen van schoolleiders voor informatiegebruik, de soorten informatie die gebruikt worden en de manier waarop informatie aangewend wordt. Daarbij verwachten we dat de doelen van Nederlandse schoolleiders om informatie te gebruiken - door de verantwoordingsgerichte verwachtingen - geïnitieerd worden vanuit een verantwoordingsperspectief en dat Vlaamse schoolleiders - door de schoolontwikkelingsgerichte verwachtingen - doelen voorop stellen vanuit een schoolontwikkelingsperspectief. Van Nederlandse schoolleiders verwachten we daarnaast dat ze, vanuit verantwoordingsgerichte verwachtingen, voornamelijk gericht zullen zijn op het gebruik van informatie over leerlingenprestaties en het verbeteren van deze output (O'Day; Schildkamp et al., 2012), terwijl Vlaamse schoolleiders vermoedelijk, vanuit schoolontwikkelingsgerichte verwachtingen, ook andere soorten informatie zullen gebruiken en sterker gericht zullen zijn op het verbeteren van onderwijsprocessen op school (O'Day, 2002). Concreet vertaalt dit zich in de volgende onderzoeksvragen:

1) Welke verwachtingen percipiëren Nederlandse en Vlaamse schoolleiders inzake informatiegebruik?

2) Welke impact hebben gepercipieerde verwachtingen inzake informatiegebruik op de doelen van Nederlandse en Vlaamse schoolleiders met betrekking tot informatiegebruik?

3) Welke impact hebben gepercipieerde verwachtingen inzake informatiegebruik op de soorten informatie die Nederlandse en Vlaamse schoolleiders gebruiken?

4) Welke impact hebben gepercipieerde verwachtingen inzake informatiegebruik op de manier waarop Nederlandse en Vlaamse schoolleiders informatie gebruiken?

\section{Theoretisch kader}

Vanuit deze onderzoeksvragen ontwikkelen we een theoretisch kader uit waarin we ervan uit gaan dat gepercipieerde verwachtingen inzake informatiegebruik verschillende componenten van het proces van informatiegebruik, zoals de doelen van informatiegebruik, de soorten informatie die schoolleiders gebruiken en de types van informatiegebruik, beïnvloeden. Dit wordt gevisualiseerd in Figuur 1. 


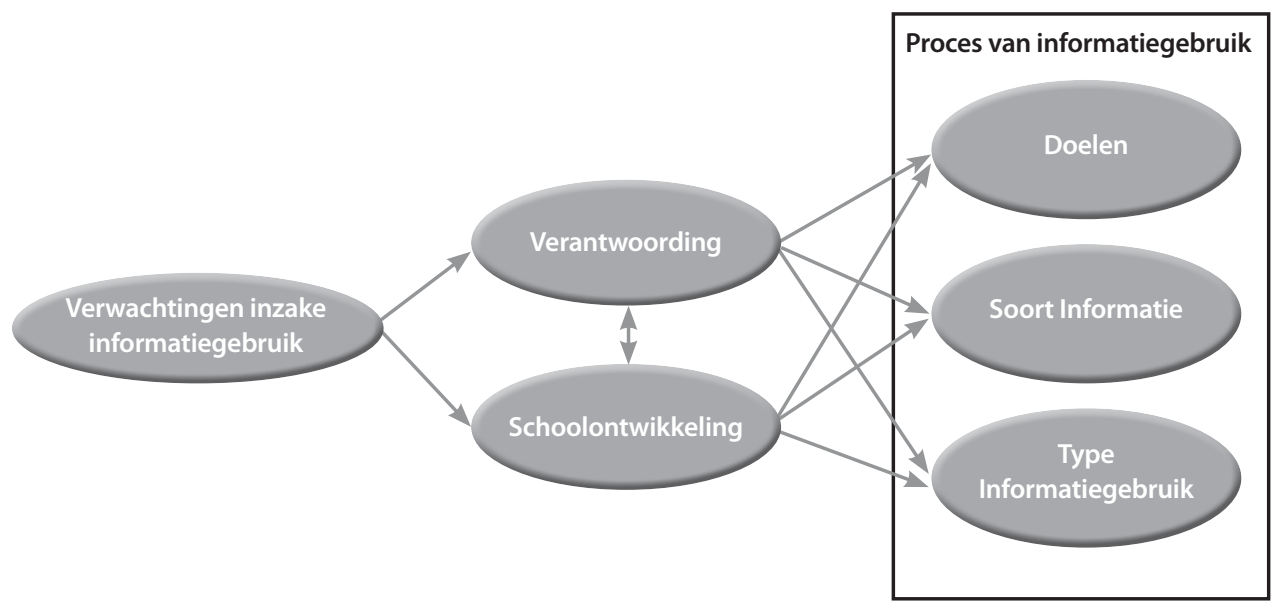

Figuur 1. Theoretisch kader

In wat volgt bespreken we de verschillende componenten van het theoretisch kader in detail. We vertrekken daarbij van de verwachtingen inzake informatiegebruik in Nederland en Vlaanderen en beschrijven vervolgens de doelen van informatiegebruik, de soorten informatie waarvan we het gebruik in deze studie beschrijven en de manieren waarop informatie gebruikt kan worden (de zogenaamde types van informatiegebruik).

\section{Verwachtingen inzake informatiegebruik}

Gelijkenissen en verschillen tussen Nederland en Vlaanderen met betrekking tot verwachtingen inzake informatiegebruik beschrijven we vanuit twee perspectieven: het schoolontwikkelingsperspectief en het verantwoordingsperspectief (Vanhoof, Vanlommel, Thys, \& Vanderlocht, 2014). In het schoolontwikkelingsperspectief vertrouwt men op de jarenlange kennis en expertise van scholen om processen binnen de school autonoom vorm te geven en te verbeteren (Eurydice, 2012; OECD, 2013), waardoor de verwachting ontstaat dat scholen via informatie inzicht verwerven in de kwaliteit van onderwijsprocessen en tot maatregelen komen om het lesgeven en leren op school te verbeteren. In het verantwoordingsperspectief hecht men belang aan de kwaliteitscontrole van scholen, waarbij men zich voornamelijk laat sturen door resultaten, eerder dan door processen (Elmore, Abelmann, \& Fuhrman, 1996). Daardoor ontstaat de verwachting dat scholen via informatie hun onderwijskwaliteit verantwoorden tegenover externen, zoals de overheid, ouders of leerlingen (OECD, 2013; Vanhoof et al., 2014). Beide perspectieven sluiten elkaar niet uit, vermits bepaalde onderwijssystemen verantwoordingsmechanismen net invoeren om schoolontwikkeling te faciliteren. Het is echter belangrijk een juiste balans te zoeken tussen schoolontwikkeling en verantwoording (Campbell \& Levin, 2009; Vanhoof \& Van Petegem, 2007). 


\section{Verwachtingen inzake informatiegebruik in Nederland en Vlaanderen}

De balans tussen verantwoordingsgerichte en schoolontwikkelingsgerichte verwachtingen inzake informatiegebruik binnen een onderwijssysteem, kunnen we beschrijven aan de hand van vier factoren.

Ten eerste worden verwachtingen inzake informatiegebruik bepaald door de autonomie van scholen in het voorop stellen van doelstellingen en normen. In onderwijssystemen met een sterkere nadruk op verantwoording expliciteert de overheid duidelijke doelstellingen en normen met betrekking tot (voornamelijk cognitieve) prestaties van leerlingen naar scholen toe, terwijl scholen in schoolontwikkelingsgerichte onderwijssystemen meer autonomie krijgen in het voorop stellen van doelen (Coghlan \& Desurmont, 2007; Eurydice, 2012; Figlio \& Page, 2003; O’Day, 2002). Op basis van deze factor kunnen we Nederland categoriseren als meer verantwoordingsgericht, vanwege duidelijke normen die door de overheid geëxpliciteerd worden onder de vorm van verwachte scores voor de school op centrale toetsen (Ehren \& Swanborn, 2012), en Vlaanderen als meer schoolontwikkelingsgericht, gezien de autonomie van scholen om naast de voorop gestelde doelstellingen van de overheid - een eigen curriculum uit te werken (De Volder, 2012; Penninckx, Vanhoof, \& Van Petegem, 2011).

Een tweede bepalende factor voor verwachtingen inzake informatiegebruik binnen het onderwijssysteem is de controle op het behalen van doelstellingen en normen. De nadruk ligt sterker op verantwoording bij de aanwezigheid van een schoolexterne meting voor doelstellingen en normen, zoals een nationale of regionale centrale toetsing (Figlio \& Page, 2003; O'Day, 2002), en sterker op schoolontwikkeling wanneer scholen meer autonomie krijgen in de methoden waarop men doelstellingen evalueert (Coghlan \& Desurmont, 2007; Eurydice, 2012). Ook op basis van deze tweede factor blijkt Nederland sterker verantwoordingsgericht, vanwege het verplicht centraal toetssysteem voor alle leeftijdsgroepen van het basisonderwijs en de landelijke centrale eindtoets aan het einde van het basisonderwijs (Ehren \& Swanborn, 2012). Vlaanderen is sterker schoolontwikkelingsgericht, vanwege de afwezigheid van een verplicht centraal toetssysteem en de eigen verantwoordelijkheid van scholen voor het genereren van informatie die inzicht biedt in de onderwijskwaliteit van de school (De Volder, 2012).

Ten derde bepalen de gevolgen van de controle op het behalen van doelstellingen en normen de balans tussen verantwoording en schoolontwikkeling. Verantwoordingsgerichte onderwijssystemen geven blijk van - voor de school onprettige - consequenties wanneer niet voldaan wordt aan de opgelegde normen, terwijl schoolontwikkelingsgerichte onderwijssystemen gericht zijn op het ontwikkelen van leermogelijkheden en het ondersteunen van schoolontwikkeling (Figlio \& Page, 2003; O’Day, 2002; OECD, 2013). Ook qua evaluatie is het Vlaamse onderwijssysteem iets schoolontwikkelingsgerichter dan het Nederlandse, gezien de onderwijsinspectie een uitgebreide sterkte/zwakte-analyse van scholen maakt, op basis waarvan scholen al dan niet met verplichte ondersteuning een verbetertraject uitwerken (De Volder, 2012). In Nederland zijn de 
resultaten van scholen op de centrale toets het uitgangspunt voor een jaarlijkse risicoanalyse door de onderwijsinspectie, op basis waarvan bepaalde scholen intensiever doorgelicht en opgevolgd worden, terwijl andere scholen een basistoezicht krijgen (De Volder, 2012; Ehren \& Honingh, 2011).

Een laatste factor is de openbaarheid van informatie over schoolkwaliteit. In verantwoordingsgerichte onderwijssystemen wordt informatie over de kwaliteit van scholen doorgaans openbaar gemaakt, bijvoorbeeld via publieke databanken of rankings van scholen, terwijl dit in schoolontwikkelingsgerichte onderwijssystemen niet gangbaar is gezien het formatief karakter dat men toekent aan evaluaties (Figlio \& Page, 2003; O’Day, 2002; Van Petegem et al. 2005; OECD, 2013). Met betrekking tot het openbaar karakter van schoolkwaliteit blijkt Nederland in vergelijking met Vlaanderen sterker verantwoordingsgericht, vanwege de publieke toegankelijkheid van databanken van de onderwijsinspectie en de publicatie van een lijst met 'zeer zwakke' scholen, terwijl het openbaar karakter van schoolkwaliteit zich in Vlaanderen beperkt tot het integraal beschikbaar maken van inspectieverslagen van scholen (De Volder, 2012; OECD, 2013).

\section{Doelen met betrekking tot informatiegebruik}

Om gelijkenissen en verschillen in het informatiegebruik van Nederlandse en Vlaamse schoolleiders te beschrijven, brengen we de doelen van schoolleiders om informatie te gebruiken in kaart. Ook deze doelen kunnen voortvloeien vanuit een verantwoordingsperspectief, zoals het gebruik van informatie om leerkrachten ter verantwoording te stellen voor de onderwijskwaliteit op school of om de schoolkwaliteit te verantwoorden ten opzichte van de onderwijsinspectie (Coburn \& Talbert, 2006; Schildkamp \& Kuyper, 2010; Wayman \& Stringfield, 2006), of vanuit een schoolontwikkelingsperspectief, zoals het gebruik van informatie om de schoolkwaliteit te monitoren, verbeteracties voorop te stellen of voor beleidsontwikkeling en -planning (Coburn \& Talbert, 2006; Schildkamp \& Kuyper, 2010).

\section{Soorten informatie}

Vervolgens gaan we na welke soorten informatie Nederlandse en Vlaamse schoolleiders aanwenden om hun beleid vorm te geven via het CIPO-model (Kellaghan \& Stufflebeam, 2003; Scheerens, 1990), dat acroniem staat voor 'context', 'input', 'proces' en 'output' van de school en de klas. Dit model komt tegemoet aan de wetenschappelijke kritiek op het verengen van het concept informatie tot kwantitatieve leerlingenresultaten omdat de verschillende soorten informatie in het kader een kwalitatieve en kwantitatieve invulling kunnen krijgen (Hulpia, Valcke, \& Verhaeghe, 2004; Schildkamp \& Kuyper, 2010). De 'context' omvat alle omgevingsfactoren die op de school en de klas afkomen, zonder dat men er een directe invloed op kan uitoefenen. De 'input' wijst op de kenmerken, capaciteiten en competenties van de mensen die samen school maken, zoals leerlingen, leerkrachten, ouders of bestuur. Het 'proces' duidt op de wijze waarop resultaten tot stand en kan zowel samenwerkings- en besluitvor- 
mingsprocessen als leerprocessen van leerlingen omvatten. Het concept 'output' wijst ten slotte op de uiteindelijke resultaten, zoals leerresultaten of extern rendement. Om het concept informatie verder af te bakenen, kiezen we ervoor om in deze studie enkel CIPO-informatie mee op te nemen die door gebruikers direct gerelateerd kan worden aan kernprocessen van de school en dus (1) (on) rechtstreeks gerelateerd is aan het leren van leerlingen, (2) een bijdrage kan leveren aan de interne kwaliteitszorg van de school of (3) besluitvorming met betrekking tot het algemene schoolbeleid kan ondersteunen.

\section{Types informatiegebruik}

Gelijkenissen en verschillen in informatiegebruik beschrijven we op basis van verschillende types informatiegebruik die Rossi, Lipsey, en Freeman (2004) onderscheiden: (1) instrumenteel gebruik, (2) conceptueel gebruik en (3) symbolisch gebruik. Visscher en Coe (2003) voegen hier een vierde vorm van informatiegebruik aan toe: (4) strategisch gebruik.

In instrumenteel informatiegebruik komt men op basis van informatie tot verbeteracties, gedragsveranderingen of besluitvormingsprocessen binnen de school of de klas (Johnson, 1998; Rossi et al., 2004). Voorbeelden zijn onder meer het afvoeren van een methode op basis van tegenvallende leerresultaten, het beter afstemmen van leerprocessen op de doelgroep of het doorvoeren van structurele aanpassingen binnen de school (Johnson, 1998).

Conceptueel informatiegebruik beïnvloedt processen binnen de school op een indirecte manier, bijvoorbeeld via veranderingen in denkprocessen, waardoor de impact van informatiegebruik op de beleidsvoering en besluitvormingsprocessen pas op langere termijn duidelijk wordt (Johnson, 1998; Rossi et al., 2004). Voorbeelden zijn onder meer de ontwikkeling van nieuwe ideeën of een meer genuanceerde kijk op het leren van leerlingen (Johnson, 1998; Schildkamp \& Teddlie, 2008; Verhaeghe, Vanhoof, Valcke, \& Van Petegem, 2010a).

In symbolisch informatiegebruik wordt informatie gebruikt om persoonlijke voordelen te bewerkstelligen (Johnson, 1998). Informatie kan legitimerend gebruikt worden, bijvoorbeeld om eerder genomen (beleids)beslissing te verantwoorden op basis van informatie die men ter beschikking krijgt (Johnson, 1998), of ter argumentatie, bijvoorbeeld om overtuigingen te sterken of mythes te ontkrachten (Visscher, 2002; Weiss, 2001).

Ten slotte kan informatie ook strategisch gebruikt worden (Visscher \& Coe, 2003), bijvoorbeeld onder de vorm van teaching to the test, het selecteren van (sterke) leerlingen om deel te nemen aan centrale toetsen, het informeren van de onderwijsinspectie over de schoolkwaliteit of het maken van publiciteit met het oog op het werven van nieuwe leerlingen (Schildkamp \& Teddlie, 2008; Visscher \& Coe, 2003; Van Petegem et al., 2005; Verhaeghe et al., 2010a). 


\section{Methode}

Met het oog op een diepgaande beschrijving van informatiegebruik vanuit een internationaal perspectief kozen we voor een kwalitatief onderzoeksdesign met semi-gestructureerde diepte-interviews. Rekening houdend met het saturatiepunt en voldoende heterogeniteit in de dataverzameling, verzamelden we data bij 12 schoolleiders, evenredig verdeeld over Nederland en Vlaanderen (Guest, Bunce, \& Johnson, 2006; Morrow, 2005). De diepte-interviews werden afgenomen door eenzelfde onderzoeker met behulp van een interviewleidraad waarin de topics uit het theoretisch kader geoperationaliseerd werden. Vervolgens werden de interviews, met een gemiddelde interviewduur van een uur, ad verbatim getranscribeerd en gecodeerd met behulp van het softwarepakket Nvivo.

In deze studie werd uitgegaan van een conceptuele equivalentie (Standaert, 2007), of de overeenkomst tussen de onderzochte concepten in verschillende onderwijssystemen, vanuit de wetenschap dat belangrijke concepten met betrekking tot informatiegebruik gedefinieerd werden op basis van literatuur uit verschillende onderwijssystemen. De codering verliep bijgevolg hoofdzakelijk deductief, volgens een codeboek met generieke hoofdconcepten en specifieke deelconcepten dat gebaseerd werd op het theoretisch kader. Als generiek concept vinden we bijvoorbeeld 'verwachtingen inzake informatiegebruik' terug in het codeboek, waarbij dit concept verder uitgesplitst wordt in specifieke codes zoals 'verwachtingen naar schoolontwikkeling' en 'verwachtingen naar verantwoording'. De constructvaliditeit van de codering werd getest door een aantal interviews door meerdere onderzoekers onafhankelijk van elkaar te laten coderen. De interbeoordelaarsbetrouwbaarheid (Miles \& Huberman, 1994), of de verhouding tussen het aantal overeenkomsten in de codering en het totale aantal toegekende codes, bedraagt $85.7 \%$.

In de interviews werd zowel vanuit de theorie als vanuit de respondenten gezocht naar patronen, volgens de principes van de kaderanalyse (Maso \& Smaling, 1998), waarbij er over de verschillende scholen heen (cross-case analysis) resultaten gegenereerd werden (Miles \& Huberman, 1994). Naast de beschrijving en concretisering van deze algemene vaststellingen via de inbreng van schoolleiders wilden we echter inzicht verwerven in de intensiteit in de codering om het belang van bepaalde concepten in het informatiegebruik van Nederlandse en Vlaamse schoolleiders in te schatten. Omdat simpele codetellingen hierin verhelderend kunnen werken (Pope, Ziebland, \& Mays, 2000; Pratt, 2009), streefden we bijkomend naar een voorzichtige kwantificering van de verschillende codes uit het codeboek. Om de validiteit van deze kwantificeringen te waarborgen werden tekstfragmenten slechts in een codetelling opgenomen indien deze in de context van het interview een unieke bijdrage leverden aan de desbetreffende code, waardoor voorbeelden die meermaals gerapporteerd worden slechts één keer in de codetelling voorkomen. Wanneer we deze methodiek concretiseren naar bijvoorbeeld verwachtingen inzake informatiegebruik voor verantwoording, wijst een groter aantal tekstfragmenten over de scholen heen 
op meer verschillende voorbeelden van hoe deze verwachtingen binnen scholen tot uiting komen.

\section{Resultaten}

Voor de beschrijving van de onderzoeksresultaten vertrekken we vanuit de vier vooropgestelde onderzoeksvragen. We beschrijven in eerste instantie de gepercipieerde verwachtingen inzake informatiegebruik in Nederland en Vlaanderen, gevolgd door de doelen voor informatiegebruik, de soorten informatie die gebruikt worden en de types informatiegebruik in Nederland en Vlaanderen.

\section{Gepercipieerde verwachtingen inzake informatiegebruik}

Zowel Nederlandse als Vlaamse schoolleiders rapporteren schoolontwikkelingsgerichte verwachtingen inzake informatiegebruik vanuit onder meer ouders, het schoolbestuur en ook de inspectie. Deze verwachtingen zijn volgens schoolleiders soms impliciet aanwezig, maar worden volgens hen ook expliciet gemaakt in onder meer gesprekken met ouders of omdat het schoolbestuur vraagt om de doelstellingen voor de komende jaren door te sturen. Een belangrijke stakeholder van waaruit verwachtingen naar informatiegebruik ervaren worden is de onderwijsinspectie. Volgens een aantal Vlaamse schoolleiders kunnen ook verwachtingen van de onderwijsinspectie voortvloeien vanuit een schoolontwikkelingsperspectief.

"Als de inspectie komt, moet je wel kunnen aantonen dat je goed bezig bent, dat je weet wat er in de leerlijnen staat en dat je daar naar handelt. Maar ik voel dat niet aan als verantwoording, want uiteindelijk is dat om je kinderen beter onderwijs te bieden." (Schoolleider Vlaanderen, respondent 3)

In tegenstelling tot Vlaamse schoolleiders geven Nederlandse schoolleiders aan dat de balans tussen schoolontwikkeling en verantwoording in de verwachtingen inzake informatiegebruik overhelt naar het verantwoordingsperspectief. De verwachtingen inzake informatiegebruik voor verantwoording vloeien volgens Nederlandse schoolleiders voornamelijk voort uit het behalen van landelijke normen op centrale toetsen. Deze scores zijn volgens hen de eerste en belangrijkste indicator voor schoolkwaliteit, op basis waarvan onder meer het schoolbestuur, de gemeente en - niet onbelangrijk - de onderwijsinspectie verantwoording vraagt. De verwachtingen inzake informatiegebruik naar verantwoording worden in Nederland zeer expliciet ervaren, bijvoorbeeld doordat het schoolbestuur en het gemeentebestuur schoolleiders vragen om de resultaten van de school voor de genormeerde toetsen door te sturen en uitleg te verschaffen bij tegenvallende resultaten. Door de grote nadruk op landelijke toetsscores geeft een aantal Nederlandse schoolleiders aan dat niet de onderwijsprocessen binnen de klas en de school voor externen de basis vormen voor 
discussie, maar wel (de evolutie van) de outputresultaten van de school. Volgens Nederlandse schoolleiders vloeien verwachtingen inzake informatiegebruik dan ook in de eerste plaats voort vanuit een verantwoordingsperspectief en slechts in tweede instantie vanuit een schoolontwikkelingsperspectief.

"Externen kijken eerst van wat is je cito-eindtoets score geweest? Is die voldoende geweest, dan laten we die school met rust. Is die onvoldoende, dan gaan we in die school kijken. Op dat moment gaan ze pas kijken naar je schoolontwikkeling." (Schoolleider Nederland - respondent 8)

In Vlaanderen ligt dit volgens de bevraagde schoolleiders enigszins anders. Door de afwezigheid van een centraal toetssysteem leggen schoolleiders rekenschap af ten opzichte van het schoolbestuur en de onderwijsinspectie op basis van zelf verzamelde context-, input-, proces- en outputinformatie. Vlaamse schoolleiders geven aan dat onder meer het schoolbestuur en de onderwijsinspectie wel inzicht willen krijgen in de resultaten van de school en dat zij hier het nodige 'bewijsmateriaal' voor vragen, maar over het algemeen komen verantwoordingsgerichte verwachtingen inzake informatiegebruik minder frequent en minder intensief naar voren in de interviews met Vlaamse schoolleiders.

Een gelijkenis tussen Nederland en Vlaanderen met betrekking tot de perceptie van verwachtingen inzake informatiegebruik voor verantwoording is dat schoolleiders uit beide onderwijssystemen aangeven dat ouders hoe langer hoe meer verantwoording vragen van scholen, bijvoorbeeld door aan te tonen dat de school hun zoon of dochter zo goed mogelijk voorbereidt met het oog op het vervolgonderwijs.

"Je moet steeds meer kunnen vertellen wat je hebt gedaan dan alleen maar: "Jantje heeft voor rekenen een 7." Dat was vroeger voldoende voor de ouders, maar tegenwoordig niet meer." (Schoolleider Nederland - respondent 8)

Uit de kwantificering van de evidentie met betrekking tot de verwachtingen inzake informatiegebruik stellen we vast dat Vlaamse schoolleiders over het algemeen minder voorbeelden rapporteren van verwachtingen inzake informatiegebruik dan Nederlandse schoolleiders (zie figuur 2: 22 getelde fragmenten voor Vlaanderen t.o.v. 59 voor Nederland). Dit betekent dat Nederlandse schoolleiders in de interviews meer verschillende voorbeelden aanhalen van hoe verwachtingen inzake informatiegebruik voor hen tot uiting komen. Bovendien leiden we af dat de gepercipieerde verwachtingen inzake informatiegebruik in Vlaanderen evenwichtig verdeeld zijn over het schoolontwikkelingsperspectief en het verantwoordingsperspectief (telkens 11 voorbeelden per code), terwijl in Nederland meer verantwoordingsgerichte verwachtingen inzake informatiegebruik gepercipieerd worden (45 tekstfragmenten voor de code 'verwachtingen naar verantwoording' t.o.v. 14 tekstfragmenten voor de code 'verwachtingen naar schoolontwikkeling'). De mate waarin verwachtingen inzake informatie- 
gebruik voor schoolontwikkeling ervaren worden is gelijklopend in Nederland en Vlaanderen.

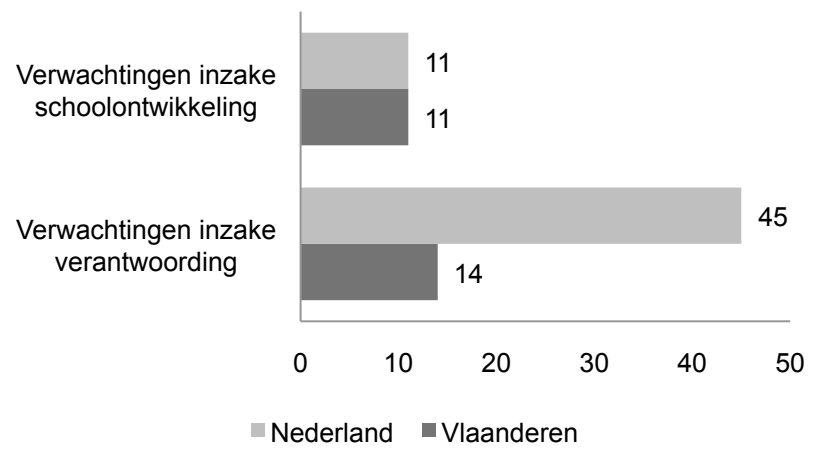

Figuur 2. Aantal verwijzingen naar gepercipieerde verwachtingen inzake informatiegebruik van schoolleiders in Nederland en Vlaanderen.

Wat betreft de gepercipieerde verwachtingen inzake informatiegebruik kunnen we de hypothese dat gepercipieerde verwachtingen inzake informatiegebruik in Nederland voornamelijk vanuit een verantwoordingsperspectief voortvloeien, aannemen. We kunnen echter niet concluderen dat verwachtingen inzake informatiegebruik door Vlaamse schoolleiders - zoals we zouden verwachten - (voornamelijk) vanuit een schoolontwikkelingsperspectief gepercipieerd worden. Vlaamse schoolleiders rapporteren minder voorbeelden van verwachtingen inzake informatiegebruik en percipiëren deze verwachtingen zowel vanuit een schoolontwikkelingsperspectief als vanuit een verantwoordingsperspectief.

\section{Doelen voor informatiegebruik en de impact van gepercipieerde verwachtingen}

Doelen voor informatiegebruik in het kader van schoolontwikkeling zijn gelijksoortig in Nederland en Vlaanderen en kunnen we op basis van de interviews uitsplitsen in drie categorieën. Ten eerste is volgens Nederlandse en Vlaamse schoolleiders informatiegebruik in het kader van visieontwikkeling noodzakelijk om beleid te voeren. Concreet zoeken schoolleiders bijvoorbeeld informatie op over welke bijdrage tablets kunnen leveren in het differentiëren op school om de afweging te maken of het differentiëren met behulp van tablets waardevol is om de komende jaren met de school naartoe te werken. Daarnaast onderscheiden we doelen die we kunnen onderbrengen in een categorie kwaliteitsbewaking. Schoolleiders gebruiken bijvoorbeeld resultaten van leerlingen voor wiskunde over de jaren heen om te monitoren of de schoolkwaliteit gewaarborgd blijft, verbetert of achteruit gaat.

"Wat ik wel belangrijk vind is dat als je merkt na een paar jaar altijd dezelfde hiaten hebt op die toetsen, dat je wel eens moet gaan kijken waar het probleem zit." (Schoolleider Vlaanderen, respondent 4) 
Ten slotte onderscheiden we in het kader van schoolontwikkeling doelen die we kunnen onderbrengen in een categorie kwaliteitsverbetering, waarbij het uitgangspunt van informatiegebruik is om informatie te gebruiken met het oog op het ondernemen van acties die de onderwijskwaliteit op school kunnen verbeteren. Een Nederlandse schoolleider geeft bijvoorbeeld aan dat de citotoetsresultaten op school ook gebruikt worden om leerlingen in te delen in differentiatiegroepen.

\section{Doelen voor informatiegebruik vanuit een verantwoordingsper-} spectief blijken uit de interviews verschillende vormen aan te kunnen nemen naargelang de focus en het onderwerp van de verantwoording. In informatiegebruik voor verantwoording kunnen we een interne versus een externe focus onderscheiden. Met interne verantwoording bedoelen we verantwoording binnen de school zelf, bijvoorbeeld wanneer schoolleiders leerkrachten ter verantwoording roepen op basis van (aanhoudende) tegenvallende resultaten op centrale toetsen. Externe verantwoording is dan weer gericht op verantwoording naar externen toe, wanneer schoolleiders bijvoorbeeld een jaarplan voor de school opstellen in functie van een nakend inspectiebezoek.

Daarnaast maken we een onderscheid naargelang het onderwerp van de verantwoording, dat productgericht of procesgericht kan zijn. Informatiegebruik voor productgerichte verantwoording betreft het gebruik van informatie met als achterliggende doel het aantonen dat bepaalde resultaten bereikt worden. Nederlandse en Vlaamse schoolleiders gebruiken bijvoorbeeld leerlingenresultaten voor taal of wiskunde met als doel aan het schoolbestuur of de onderwijsinspectie aan te tonen dat de school goed bezig is.

"De cito-methodegebonden toetsen en niet-methodegebonden toetsen worden opgeslagen en die informatie gebruiken we om verantwoording af te leggen aan het schoolbestuur en de rijksinspectie." (Schoolleider Nederland, respondent 6)

Uit de interviews komt echter ook naar voren dat informatie een middel kan zijn om aan te tonen dat er binnen de school kwaliteitsvol onderwijs geboden wordt of - met andere woorden - om processen binnen de school te verantwoorden. Met het oog op de verantwoording van de begeleiding of remediering van leerlingen ten opzichte van ouders, wordt er volgens schoolleiders bijvoorbeeld informatie bijgehouden over hoe leerlingen geremedieerd worden bij problemen die zich voordoen.

Figuur 3 geeft weer in hoeverre we binnen Nederland en Vlaanderen evidentie vinden voor zowel verantwoordingsdoelen als schoolontwikkelingsdoelen met betrekking tot informatiegebruik. We stellen vast dat schoolleiders informatie naar eigen zeggen voornamelijk gebruiken met het oog op schoolontwikkeling en veel minder met het oog op verantwoording. Ondanks de sterke verwachtingen naar verantwoording in het Nederlandse onderwijssysteem, is de aard van de doelen om informatie te gebruiken niet verschillend in Nederland en Vlaanderen en is ook de intensiteit waarmee schoolontwikkelings- en 
verantwoordingsdoelen in de interviews naar voren komen gelijkaardig. Op basis van deze bevindingen kunnen we dus niet aannemen dat gepercipieerde verwachtingen inzake informatiegebruik de doelen voor informatiegebruik beinvloeden.

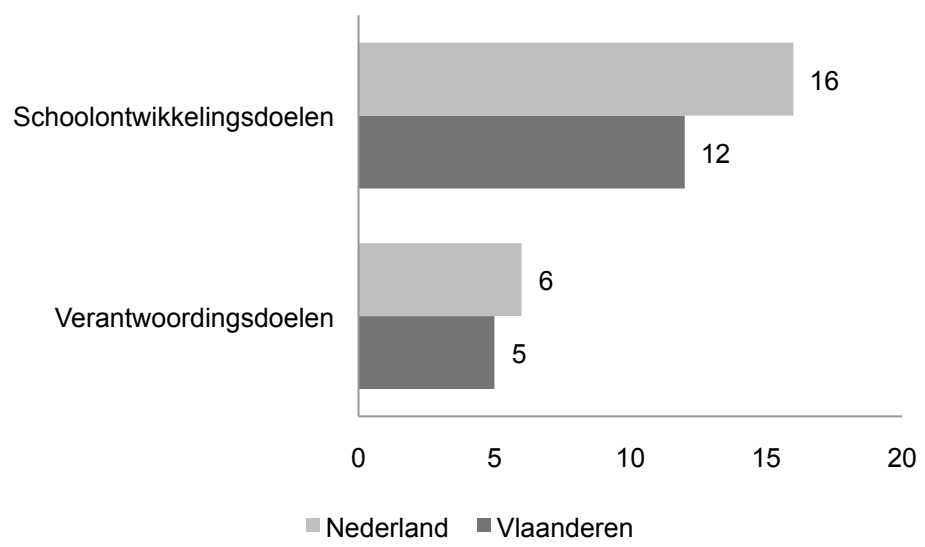

Figuur 3. Aantal verwijzingen naar doelen voor informatiegebruik in Nederland en Vlaanderen.

\section{Soorten gebruikte informatie en de impact van gepercipieerde verwachtingen}

Zowel Nederlandse als Vlaamse schoolleiders gebruiken context-, input-, proces- en outputinformatie om hun beleid vorm te geven.

In Nederland en Vlaanderen wordt ten eerste contextinformatie met betrekking tot de (regulering van de) school- en klasorganisatie gebruikt. In deze categorie komen zowel citaten naar voren van informatie waaraan schoolleiders wettelijk gebonden zijn, zoals regelgeving of leerdoelen, als citaten van informatie waaraan zij niet wettelijk gebonden zijn, zoals visieteksten, beleidsplannen of de schoolbegroting. Daarnaast gebruiken Nederlandse en Vlaamse schoolleiders contextinformatie met betrekking tot het onderwijslandschap, zoals geboortecijfers en omgevingsanalyses.

"Leerlingenbeleid, dat zijn ook gegevens van in de stad. Hoeveel kinderen wonen er hier in de buurt? Welke kinderen wonen hier in de buurt? Welke leeftijdscategorieën wonen hier in de buurt?" (Schoolleider Vlaanderen, respondent 5)

In de citaten met betrekking tot het gebruik van inputinformatie herkennen we in eerste instantie algemene gegevens over de schoolpopulatie. Voorbeelden zijn onder meer het in kaart brengen van leerlingenstromen, doelgroepleerlingen of tendensen binnen de school. Daarnaast geven Nederlandse en Vlaamse schoolleiders aan inputinformatie te gebruiken met betrekking tot de beginsituatie en het schools functioneren van leerlingen omdat deze kenmerken van leerlingen hun leren in positieve of negatieve zin kunnen beïnvloeden. Con- 
creet documenteert men daarom bepaalde leerstoornissen, de thuistaal van leerlingen of informatie over de eerdere (cognitieve) ontwikkeling van leerlingen.

"De kinderen die hier starten bij de kleuters hebben veelal peuterspeelzaal gedaan en daar krijgen we een evaluatielijst van. Daar staan dan heel gewone dingen: hoe de kinderen zich hebben ontwikkeld of hoe zelfstandig ze zijn,...." (Schoolleider Nederland, respondent 7)

Ten slotte gebruiken Nederlandse en Vlaamse schoolleiders naar eigen zeggen sociale achtergrondgegevens van leerlingen om een totaalbeeld van leerlingen te creëren, zoals informatie over de nationaliteit van leerlingen, het opleidingsniveau en het beroep van de ouders en de thuissituatie van leerlingen.

Procesinformatie die in zowel Nederland als Vlaanderen gebruikt wordt kan betrekking hebben op de leerling, de leerkracht of de school. Procesinformatie over het functioneren van leerlingen omvat gegevens gaande van het cognitieve leren, over de sociaal-emotionele ontwikkeling tot het gedrag van leerlingen en wordt binnen scholen doorgaans gebundeld in een leerlingvolgsysteem.

"We hebben ook het instrument van 'ZIEN!' en dat is gericht op het welbevinden van kinderen. En één tot twee keer per jaar wordt dat instrument afgenomen om te zien hoe het met het welbevinden van de kinderen zit." (Schoolleider Nederland, respondent 12)

Via onder meer klasbezoeken en functioneringsgesprekken verzamelen schoolleiders daarnaast naar eigen zeggen procesinformatie over het functioneren van leerkrachten, zoals informatie over de competenties van leerkrachten in het lesgeven of hun tevredenheid op school. Ten slotte onderscheiden we op basis van de interviews procesinformatie over het functioneren van de school, zoals de opbrengst van prioriteiten waaraan gewerkt werd of de tevredenheid van ouders over de school.

Uit de interviews stellen we verschillen vast tussen Nederlandse en Vlaamse schoolleiders. Nederlandse schoolleiders geven, meer dan Vlaamse schoolleiders, aan over een gevalideerd instrumentarium te beschikken om procesinformatie te verzamelen. Uit de interviews met Nederlandse schoolleiders blijkt een sterkere tendens naar het zo objectief mogelijk meten van procesinformatie, bijvoorbeeld via het hanteren van vragenlijstmetingen, vaardigheidsscores, registratielijsten of observatielijsten.

In de citaten rond het gebruik van outputinformatie ten slotte, onderscheiden we ten eerste outputinformatie die een beeld geeft van het rendement van de school, zoals onder meer resultaten van leerlingen in het vervolgonderwijs en gegevens over het bereiken van ontwikkelingsdoelen en eindtermen. Daarnaast gebruiken schoolleiders in Nederland en Vlaanderen ook outputinformatie met betrekking tot interne monitoring, zoals interne toetsresultaten, 
om een zicht te krijgen op het leerproces van leerlingen. De laatste categorie outputinformatie die we onderscheiden is deze met betrekking tot benchmarking, zoals leerresultaten van leerlingen in vergelijking met leerresultaten van leerlingen uit andere scholen. Een voorbeeld daarvan zijn de Cito-eindtoetsen in Nederland.

"De grote Cito-eindtoetsen worden landelijk afgenomen en aan de hand daarvan kan je dus peilen hoe jouw school er voor staat." (schoolleider Nederland, respondent 8)

Nederland en Vlaanderen verschillen wat betreft het gebruik van outputinformatie. Het gebruik van outputinformatie in het kader van het rendement van de school komt vooral naar voren in de interviews met Vlaamse schoolleiders, terwijl het gebruik van benchmarkinformatie net in Nederland sterk naar voren komt en in Vlaanderen slechts in een beperkte mate gerapporteerd wordt.

Figuur 4 geeft een samenvatting van de evidentie die we terugvinden voor het gebruik van context-, input-, proces- en outputinformatie. In de interviews met Vlaamse schoolleiders komt het gebruik van contextinformatie het sterkst naar voren (in 32 tekstfragmenten) en wordt het gebruik van input-, proces- en outputinformatie minder gerapporteerd. Nederlandse schoolleiders rapporteren daarentegen het gebruik van proces- en outputinformatie veel vaker dan Vlaamse schoolleiders. Informatiegebruik in Nederland is dus sterker gericht op leerlingenprestaties dan in Vlaanderen, al maken Nederlandse schoolleiders ook meer gebruik van procesinformatie.

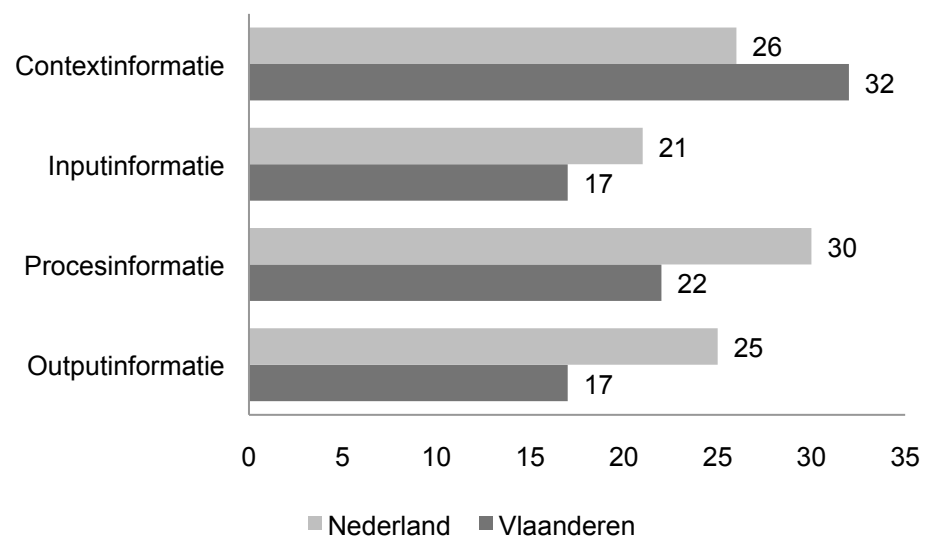

Figuur 4. Aantal verwijzingen naar het gebruik van context-, input-, proces- en outputinformatie in Nederland en Vlaanderen. 


\section{Types van informatiegebruik en de impact van gepercipieerde verwachtingen}

\section{Instrumenteel informatiegebruik}

De evidentie rond instrumenteel informatiegebruik kunnen we onderverdelen in twee categorieën. De eerste betreft instrumenteel informatiegebruik in functie van het onderwijs en leren op school, waarmee we doelen op onder meer een andere pedagogische of didactische aanpak in de klas, het doorvoeren van nieuwe methoden of het introduceren van een (thema)project.

"Uit de doorlichting bleek dat niet alle aspecten van muzische vorming in elke klas aan bod kwamen. Die informatie heeft ertoe geleid dat we een klasdoorbrekend doorschuifsysteem geïntroduceerd hebben, waardoor elke leerkracht zich kan toeleggen op zijn of haar muzische specialiteiten." (Schoolleider Vlaanderen, respondent 3)

Daarnaast onderscheiden we een categorie instrumenteel informatiegebruik in functie van de schoolorganisatie en het schoolbeleid, zoals het introduceren van een nieuwe klassenstructuur binnen de school, budgettaire aanpassingen of het vooropstellen van (nieuwe) schooldoelstellingen.

We stellen inhoudelijke verschillen vast tussen Nederland en Vlaanderen met betrekking tot instrumenteel informatiegebruik. De voorbeelden van instrumenteel informatiegebruik van Nederlandse schoolleiders geven blijk van zeer leerling- en klasgerichte acties op basis van informatie, zoals het uitwerken van handelingsplannen, het samenstellen van differentiatiegroepen of het bepalen van specifieke doelstellingen voor leerlingen, terwijl de acties die Vlaamse schoolleiders rapporteren eerder algemeen en voor de hele school bedoeld zijn, zoals het invoeren van een nieuwe methode of een project of het heroverwegen van de klassenindeling.

\section{Conceptueel informatiegebruik}

Conceptueel informatiegebruik kunnen we indelen in drie categorieën. De eerste is conceptueel informatiegebruik in functie van het onderwijs en leren. Achtergrondinformatie over leerlingen kan bijvoorbeeld meer inzicht verschaffen in leerlingen, waardoor men gaat nadenken over hoe men ervoor kan zorgen dat het kind zich goed voelt op school. Daarnaast onderscheiden we een categorie rond conceptueel informatiegebruik in functie van de schoolorganisatie en het schoolbeleid. Demografische gegevens uit de schoolbuurt kunnen er bijvoorbeeld toe leiden dat schoolleiders nadenken over een nakend plaatstekort in de school. De laatste categorie betreft conceptueel informatiegebruik in functie van kwaliteitsbewaking en - verbetering. In deze voorbeelden worden resultaten van leerlingen in het vervolgonderwijs door schoolleiders bijvoorbeeld gebruikt om af te toetsen of de school leerlingen goed adviseert met het oog op 
het vervolgonderwijs of om na te gaan of de school leerlingen goed voorbereidt op het vervolgonderwijs.

"Adviezen houden wij bij om te zien of onze manier van werken goed resulteert in het secundair onderwijs." (Schoolleider Vlaanderen, respondent 2)

We stellen inhoudelijke verschillen vast tussen Nederland en Vlaanderen in conceptueel informatiegebruik. Conceptueel informatiegebruik in functie van het onderwijs en leren krijgt in Vlaanderen een zeer algemene invulling, zoals het ontwikkelen van een visie op basis van informatie over onderwijsvernieuwingen, terwijl dit informatiegebruik in Nederland sterker gefocust is op leerlingen, zoals het reflecteren over een specifieke lesaanpak op basis van leerresultaten van leerlingen. Met betrekking tot conceptueel informatiegebruik in functie van kwaliteitsbewaking en -verbetering geven Nederlandse schoolleiders meer blijk van het systematisch bekijken, vergelijken, bespreken en voorspellen van leerlingenresultaten van de school.

\section{Symbolisch informatiegebruik}

Citaten rond symbolisch informatiegebruik leiden tot drie categorieën, die gelijklopend zijn met de categorieën binnen conceptueel informatiegebruik. Ten eerste definiëren we symbolisch informatiegebruik in functie van het onderwijs en leren op school. Schoolleiders gebruiken bijvoorbeeld wetenschappelijke artikelen over differentiatiemethoden om het schoolteam de meerwaarde ervan te doen inzien. De tweede categorie betreft symbolisch informatiegebruik in functie van schoolorganisatie en -beleid. Cijfers over pestgedrag kunnen volgens schoolleiders bijvoorbeeld een aanleiding zijn om het schoolteam te overtuigen van het belang van een pestbeleid.

"We hebben meegedaan aan de onderwijsinnovatiegroep over pesten en dan zie je dat ongeveer $8 \%$ van de kinderen een ervaring heeft met pesten. Dan ga je analyseren om te zien waar het door komt. Dit zeggen de kinderen en wat gaan wij daar mee doen? Dat is een koevoet tussen de deur." (Schoolleider Nederland, respondent 9

Ten slotte vinden we ook symbolisch informatiegebruik met betrekking tot kwaliteitsbewaking en - verbetering terug. Concreet kunnen leerlingenresultaten volgens schoolleiders bijvoorbeeld een uitgangspunt vormen om leerkrachten op hun sterke punten en verbeterpunten te wijzen.

Wat betreft symbolisch informatiegebruik stellen we geen verschillen vast tussen Nederlandse en Vlaamse schoolleiders.

\section{Strategisch informatiegebruik}

In de citaten rond strategisch informatiegebruik onderscheiden we twee categorieën. De eerste betreft strategisch informatiegebruik in functie van schoolprofi- 
lering, waarbij men de school op de kaart wil zetten. Dit doet men door bijvoorbeeld uitzonderlijke prestaties op een technologiewedstrijd te publiceren op de website of in het maandblad van de school. Daarnaast onderscheiden we strategisch informatiegebruik in functie van de toenemende verantwoordingsdruk. Schoolleiders documenteren bijvoorbeeld uitgevoerde remediëringsactiviteiten voor leerlingen om zich op voorhand in te dekken wanneer een advisering door ouders niet aanvaard zou worden.

"Op het moment dat er een klacht komt, zijn al ontzettend veel interventies gepleegd. Op het moment dat de ouder bij mij komen en vinden dat het kind hier te weinig leert, dan heb ik vaak al een heel dossier liggen..."

(Schoolleider Nederland, respondent 10)

Nederlandse en Vlaamse schoolleiders verschillen wat betreft strategisch informatiegebruik. Vlaamse schoolleiders rapporteren enkel strategisch informatiegebruik in functie van schoolprofilering en slechts in beperkte mate in functie van de toenemende verantwoordingsdruk, terwijl deze laatste vorm van strategisch informatiegebruik in de Nederlandse interviews meermaals naar voren komt.

Verder blijkt uit de interviews met Nederlandse schoolleiders dat er soms strategieën ontwikkeld worden om 'betere' leerlingenprestaties voor te leggen, zoals teaching to the test en oefenen met de centrale toetsen. Bovendien geven twee schoolleiders aan voorzichtig te zijn met het inschrijven van leerlingen die in het verleden zwak gescoord hebben op de nationale toets.

"Kinderen maken de toets en mogen die overdoen, als blijkt dat dit niet overeen komt met de Cito-entree toetsen." (Schoolleider Nederland, respondent 12)

Figuur 5 geeft een overzicht van het aantal citaten die we voor de verschillende vormen van informatiegebruik terugvinden in Nederland en Vlaanderen. We stellen vast dat schoolleiders slechts in beperkte mate symbolisch en strategisch informatiegebruik rapporteren. In Vlaanderen blijft al bij al blijft ook instrumenteel en conceptueel informatiegebruik beperkt, terwijl Nederlandse schoolleiders hier meer voorbeelden van geven (28 voorbeelden van instrumenteel gebruik en 38 voorbeelden van conceptueel gebruik).

Op basis van deze resultaten concluderen we dat informatie in Nederland en Vlaanderen anders gebruikt wordt. In Nederland wordt informatie meer instrumenteel en conceptueel gebruikt en is het informatiegebruik, in tegenstelling tot wat we verwacht hadden, sterker gericht op het verbeteren van onderwijsprocessen dan in Vlaanderen. Nederlandse schoolleiders rapporteren daarnaast strategieën om betere leerlingenprestaties te kunnen voorleggen, terwijl we hier in Vlaanderen geen evidentie voor vinden. 


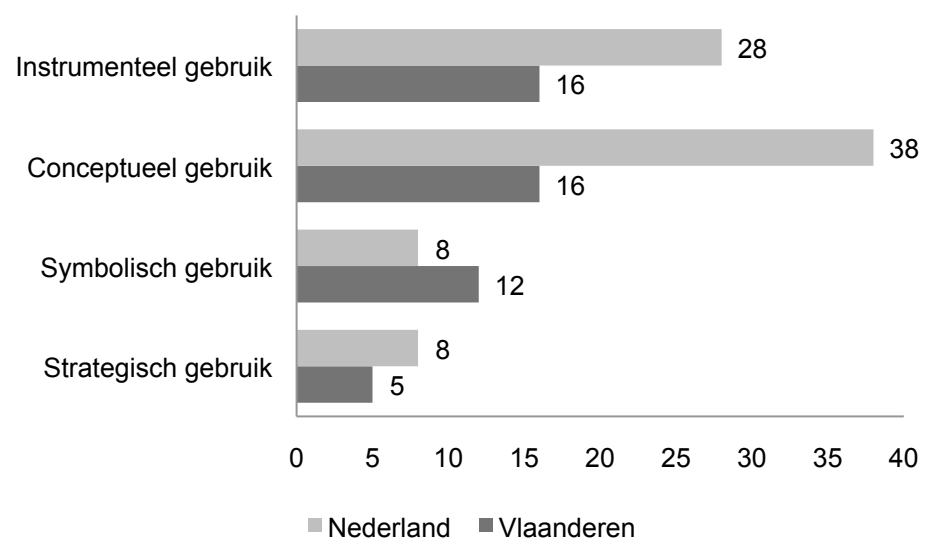

Figuur 5. Aantal verwijzingen naar instrumenteel, conceptueel, symbolisch en strategisch informatiegebruik in Nederland en Vlaanderen.

\section{Conclusie en discussie}

De onderzoeksresultaten van deze studie wijzen op verschillen in het informatiegebruik in verantwoordingsgerichte en schoolontwikkelingsgerichte onderwijssystemen. Zoals verwacht op basis van de sterk outputgerichte onderwijsinspectie in Nederland (De Volder, 2012; OECD, 2013) percipiëren Nederlandse schoolleiders verwachtingen inzake informatiegebruik voornamelijk vanuit een verantwoordingsperspectief. In Vlaanderen percipiëren schoolleiders minder verwachtingen en is er sprake van een balans tussen verantwoording en schoolontwikkeling in deze verwachtingen. De sterk verantwoordingsgerichte verwachtingen inzake informatiegebruik in Nederland beïnvloeden de feitelijke doelen van schoolleiders niet, vermits deze zowel in Nederland als in Vlaanderen gericht zijn op schoolontwikkeling. Wel stellen we verschillen vast in de soorten informatie waarvan Nederlandse en Vlaamse schoolleiders gebruik maken en de manier waarop informatie wordt gebruikt. Nederlandse schoolleiders maken, naar verwachting (O'Day, 2002; Schildkamp et al., 2012), meer gebruik van (vergelijkende) outputinformatie dan Vlaamse schoolleiders. Uit de interviews met Nederlandse schoolleiders komt echter ook meer gebruik van procesinformatie naar voren, waarbij de nadruk sterker dan in Vlaanderen komt te liggen op het in kaart brengen van het functioneren van leerlingen, leerkrachten en de school. Ten slotte geven Nederlandse schoolleiders meer blijk van conceptueel en instrumenteel informatiegebruik, waarbij zij meer dan Vlaamse schoolleiders klas- en leerlinggerichte acties rapporteren om tot beter lesgeven en leren op school te komen. De veronderstelling dat Nederlandse schoolleiders voornamelijk gericht zouden zijn op het verbeteren van leerlingenprestaties en Vlaamse schoolleiders op het verbeteren van onderwijsprocessen op school (O'Day, 2002; Schildkamp et al., 2012), gaat op basis van dit onderzoek dus niet op. 
Uit de onderzoeksresultaten kunnen we geen eenduidig positieve of negatieve impact van een schoolontwikkelingsgericht onderwijssysteem of een verantwoordingsgericht onderwijssysteem concluderen. Ondanks de sterkere verwachtingen naar verantwoording in Nederland, vloeien de feitelijke doelen van Nederlandse schoolleiders voort uit een schoolontwikkelingsperspectief. Daarnaast zijn Nederlandse schoolleiders, door de gepercipieerde verwachtingen naar verantwoording, sterker gefocust op het verbeteren van het leren van leerlingen, wat strookt met de bevindingen van O’Day (2002) en Wößmann (2002), en komen Nederlandse schoolleiders collectief meer tot instrumenteel en conceptueel informatiegebruik. Dit doet - analoog met bevindingen van Sutherland (2004) -vermoeden dat het informatiegebruik in Vlaanderen sterker afhankelijk is van de individuele motivatie en de houding van schoolleiders. We kunnen dus voorzichtig concluderen dat, ondanks de grote nadruk op verantwoording in Nederland, Nederlandse schoolleiders toch meer tot geïnformeerde schoolontwikkeling komen dan Vlaamse schoolleiders. Dit is opmerkelijk, vermits in internationale literatuur m.b.t. informatiegebruik de impact van verantwoordingsgerichte onderwijssystemen voornamelijk naar voren komt onder de vorm van resultaatsgerichte strategieën die nefast zijn voor schoolontwikkeling, zoals teaching to the test (Schildkamp et al., 2012). Aan de hand van dit onderzoek kunnen we dit beeld dus enigszins nuanceren. De vraag die zich op basis van deze studie dan ook opwerpt, is of het de aard van verwachtingen (verantwoordingsgericht of schoolontwikkelingsgericht) is die van belang is, dan wel de mate waarin verwachtingen gepercipieerd worden.

Deze studie is een eerste aanzet om meer inzicht te verwerven in de impact van het onderwijssysteem en gepercipieerde verwachtingen die daarmee gepaard gaan op het informatiegebruik in basisscholen. Onze keuze om de onderzoeksthematiek breed en diepgaand te beschrijven via een kwalitatief onderzoek bij een beperkt aantal respondenten maakt dat we de onderzoeksresultaten van deze studie met de nodige omzichtigheid moeten behandelen. Toch biedt deze studie een aantal aanknopingspunten om vervolgonderzoek naar informatiegebruik op te zetten en om informatiegebruik voor schoolontwikkeling te faciliteren. Ten eerste is het aangewezen in vervolgonderzoek dieper in te gaan op de doelen voor informatiegebruik. Vermits ondanks de verschillen in verwachtingen inzake informatiegebruik, doelen voor informatiegebruik gelijklopend zijn in Nederland en Vlaanderen, lijkt het ons zinvol om via vervolgonderzoek inzicht te krijgen in hoe doelen voor informatiegebruik tot stand komen, rekening houdend met gebruikersgebonden factoren die informatiegebruik in scholen kunnen beïnvloeden, zoals de houding ten opzichte van informatiegebruik (Vanhoof et al., 2014). Daarnaast concluderen we dat Nederlandse schoolleiders meer gericht zijn op het gebruik van informatie over onderwijsprocessen en leerresultaten dan Vlaamse schoolleiders. Dit kan te maken hebben met het feit dat schoolleiders in Nederland een gevalideerd instrumentarium aangereikt krijgen om tot schoolontwikkeling te komen en Vlaamse schoolleiders meer op zichzelf aangewezen zijn in het meten van processen en resultaten van de 
school. De ontwikkeling van een centraal gegenereerd en gevalideerd instrumentarium om onderwijsprocessen en leerresultaten te meten en te vergelijken met deze van gelijkaardige scholen kan dus belangrijk zijn om ook scholen in schoolontwikkelingsgerichte onderwijssystemen van valide en betrouwbare informatie te voorzien en geïnformeerde schoolontwikkeling te stimuleren. Ten slotte is het internationaal karakter van deze studie een meerwaarde gebleken om informatiegebruik vanuit een breder perspectief te benaderen en leerkansen te creëren voor zowel onderzoekers, beleidsmakers als praktijkmensen. Verder inzetten op internationaal vergelijkend onderzoek naar informatiegebruik biedt mogelijkheden om meer inzicht te verwerven in (de kwaliteit van) processen en resultaten van informatiegebruik in verschillende onderwijssystemen en is noodzakelijk om informatiegebruik binnen het eigen onderwijssysteem in een breder kader te kunnen plaatsen. Daarnaast biedt internationaal vergelijkend onderzoek naar informatiegebruik op grotere schaal de mogelijkheid om een gedragen en gevalideerd kader uit te bouwen om informatiegebruik in verschillende contexten te beschrijven. Met betrekking tot informatiegebruik is internationaal vergelijkend onderzoek dus een opportuniteit opdat onderzoekers, beleidsmakers als praktijkmensen internationaal van elkaar kunnen (blijven) leren.

\title{
Noot
}

Dit artikel is mede mogelijk gemaakt door een subsidie van SIA RAAK. Het werk is uitgevoerd in het kader van het internationale project 'Schoolcijfers, een tweede natuur'. Dit project richt zich voornamelijk op het werken aan opbrengstgericht werken in het basisonderwijs en het borgen van de resultaten.

\begin{abstract}
Worldwide the use of information in schools is gaining importance. Although research often relates differences in the use of information in schools to an accountability or a school improvement perspective, little research describes and compares the use of information in different educational systems. This study therefore investigates similarities and differences in the use of information by school leaders from an accountability system versus school leaders from a school improvement system. The results show differences in school leaders' perceived expectations to use information, in the types of information they use and in the way information is used. The conclusion that stronger accountability expectations not necessarily negatively influence information use for school improvement is remarkable.
\end{abstract}




\section{Referenties}

Campbell, C., \& Levin, B. (2009). Using data to support educational improvement. Educational Assessment, Evaluation and Accountability, 21, 47-65.

Coburn, C. E., \& Talbert, J. E. (2006). Conceptions of evidence use in school districts: mapping the terrain. American Journal of Education, 112, 469-495

Coghlan, M., \& Desurmont, A. (2007). School autonomy in Europe: Policies and measures. Brussels: Eurydice.

De Volder, I. (2012). Externe schoolevaluaties in Europa. Antwerpen - Apeldoorn: Garant.

Ehren, M., \& Honingh, M. E. (2011). Risk-based school inspections in the Netherlands: a critical reflection on intended effects and causal mechanisms. Studies in educational evaluation, 37, 239-248.

Ehren, M. C. M., \& Swanborn, M. S. L. (2012). Strategic data use of schools in accountability systems. School Effectiveness and School Improvement, 23(2), 257-280.

Elmore, R. F., Abelmann, C. H., \& Fuhrman, S. H. (1996). The new accountability in state education reform: From process to performance. In H. F. Ladd (Ed.), Holding schools accountable: Performance-based reform in education (pp. 65-98). Washington, D. C.: Brookings Institution Press.

Eurydice. (2012). Key data on education in Europe 2012. Brussels: Eurydice.

Figlio, D. N., \& Page, M. E. (2003). Can school choice and school accountability successfully coexist? In C. M. Hoxby (Ed.), The economics of school choice. Chicago: University of Chicago Press.

Guest, G., Bunce, A., \& Johnson, L. (2006). How many interviews are enough? An experiment with data saturation and variability. Field Methods, 18(1), 59-82.

Hulpia, H., Valcke, M., \& Verhaeghe, J. P. (2004). The use of performance indicators in a school improvement policy. What do experts say about it? Paper presented at the American Educational Research Association, San Diego.

Johnson, R. B. (1998). Toward a theoretical model of evaluation utilization. Evaluation and Program Planning, 21(1), 93-110.

Kellaghan, T., \& Stufflebeam, D. (2003). International handbook of educational evaluation. Boston: Kluwer Academic Publishers.

Marsh, J. A., Pane, J. F., \& Hamilton, L. S. (2006). Making sense of data-driven decision making in education. Evidence from recent rand research. Santa Monica, CA: RAND Corporation.

Maso, I., \& Smaling, A. (1998). Kwalitatief onderzoek: Praktijk en theorie. Amsterdam: Boom.

Miles, M., \& Huberman, M. (1994). Qualitative Data Analysis. London: Sage.

Morrow, S. L. (2005). Quality and trustworthiness in qualitative research in counseling psychology. Journal of Counseling Psychology, 52(2), 250-260

O'Day, J. A. (2002). Complexity, accountability, and school improvement. Harvard Educational Review, 72(3), 37. Retrieved from www.politicalscience.uncc.edu website:

OECD. (2013). Synergies for better learning. An international perspective on evaluation and assessment. Paris: OECD Publishing.

Penninckx, M., Vanhoof, J., \& Van Petegem, P. (2011). Evaluatie in het Vlaamse onderwijs. Beleid en praktijk van leerling tot overheid. Antwerpen-Apeldoorn: Garant.

Pope, C., Ziebland, S., \& Mays, N. (2000). Qualitative research in health care. Analysing qualitative data. British medical journal, 320, 114-116.

Pratt, M. G. (2009). For the lack of a boilerplate: tips on writing up (and reviewing) qualitative research. Academy Of Management Journal, 52(5), 856-862.

Rossi, P. H., Lipsey, M. W., \& Freeman, H. E. (2004). Evaluation: A systematic approach (7th ed.). London, UK: Sage. 
Scheerens, J. (1990). School effectiveness research and the development of process indicators of school functioning. School Effectiveness and School Improvement, 1, 61-80.

Schildkamp, K., Ehren, M., \& Lai, M. K. (2012). Editorial article for the special issue on databased decision making around the world: from policy to practice to results. School Effectiveness and School Improvement, 23(2), 123-131.

Schildkamp, K., \& Kuyper, W. (2010). Data-informed curriculum reform: Which data, what purposes, and promoting and hindering factors. Teaching and Teacher Education, 26(3), 482496.

Schildkamp, K., Rekers-Mombarg, L. T. M., \& Harms, T. J. (2012). Student group differences in examination results and utilization for policy and school development. School Effectiveness and School Improvement, 23(2), 229-255.

Schildkamp, K., \& Teddlie, C. (2008). School performance feedback systems in the USA and in the netherlands: A comparison. Educational Research \& Evaluation, 14(3), 255-282.

Standaert, R. (2007). Vergelijken van onderwijssystemen. Leuven: Acco.

Sutherland, S. (2004). Creating a culture of data use for continuous improvement: A case study of an edison project school. The American Journal of Evaluation, 25(3), 277-293.

Van Petegem, P., Vanhoof, J., Daems, F., \& Mahieu, P. (2005). Publishing information on individual schools? Educational Research \& Evaluation, 11(1), 45-60.

Vanhoof, J., \& Van Petegem, P. (2007). Matching internal and external evaluation in an era of accountability and school development: lessons from a Flemish perspective. Studies in educational evaluation, 33(2), 101-119.

Vanhoof, J., Vanlommel, K., Thijs, S., \& Vanderlocht, H. (2014). Data use by Flemish School Principals: Impact of Attitude, Self-efficacy and External Expectations Educational Studies, 40(1), 48-62.

Verhaeghe, G., Vanhoof, J., Valcke, M., \& Van Petegem, P. (2010a). Effecten van ondersteuning bij schoolfeedbackgebruik. Pedagogische Studiën, 88, 90-106.

Verhaeghe, G., Vanhoof, J., Valcke, M., \& Van Petegem, P. (2010b). Using school performance feedback: perceptions of primary school principals. School Effectiveness and School Improvement, 21(2), 167-188.

Visscher, A. (2002). School performance feedback systems. In A. J. Visscher \& R. Coe (Eds.), School improvement through performance feedback (pp. 41-71). Lisse: Swets \& Zeitlinger.

Visscher, A., \& Coe, R. (2003). School performance feedback systems: Conceptualisation, analysis, and reflection. School Effectiveness and School Improvement, 14(3), 321-349.

Wayman, J.C., \& Stringfield, S. (2006). Technology-supported involvement of entire faculties in examination of student data for instructional improvement. American Journal of Education, 112, 549-571

Weiss, C. H. (2001). What kind of evidence in evidence-based policy? Paper presented at the Third International, Inter-Disciplinary Evidence-Based Policies and IndicatorSystems Conference, Durham, UK.

Wößmann, L. (2002). Central exams improve educational performance: international evidence Kieler Diskussionsbeiträge 397. Kiel: Institut für Weltwirtschaft. 